\title{
Factors Influencing Consumers' Purchase Intention towards Electric Two-Wheelers
}

\author{
Sudarsan Jayasingh ${ }^{1, * \mathbb{D}}$, T. Girija ${ }^{1}$ and Sivakumar Arunkumar ${ }^{2} \mathbb{D}$ \\ 1 SSN School of Management, Kalavakkam 603110, Tamil Nadu, India; girijat@ssn.edu.in \\ 2 School of Management, SASTRA Deemed University, Thanjavur 613401, Tamil Nadu, India; \\ arunkumar@mba.sastra.edu \\ * Correspondence: sudarsanj@ssn.edu.in; Tel.: +91-944-551-8581
}

Citation: Jayasingh, S.; Girija, T.; Arunkumar, S. Factors Influencing Consumers' Purchase Intention towards Electric Two-Wheelers. Sustainability 2021, 13, 12851. https:/ / doi.org/10.3390/su132212851

Academic Editor: Fabio Carlucci

Received: 12 October 2021

Accepted: 16 November 2021

Published: 20 November 2021

Publisher's Note: MDPI stays neutral with regard to jurisdictional claims in published maps and institutional affiliations.

Copyright: (c) 2021 by the authors. Licensee MDPI, Basel, Switzerland. This article is an open access article distributed under the terms and conditions of the Creative Commons Attribution (CC BY) license (https:// creativecommons.org/licenses/by/ $4.0 /)$.

\begin{abstract}
The demand for electric vehicles (EVs) has significantly increased in recent years, but it represents only a tiny percentage of the total new vehicles sold globally. In 2021, the total sales of electric two-wheelers were less than $1 \%$ only. Therefore, the adoption of an electric two-wheeler (E2W) needs to be studied. This research develops a behavioral electric two-wheelers adoption intention model. The present study aimed to identify the factors that influence consumers' intentions to adopt electric two-wheelers. The questionnaire method was employed, and 182 valid responses were collected. The partial least squares structural equation modeling (PLS-SEM) was used to test the research hypothesis. The empirical results indicate that environmental concern, perceived economic benefit, charging infrastructure, and social influence significantly impact consumers' attitudes towards electric two-wheelers. Attitude also significantly affects the consumer's intention to purchase an electric two-wheeler. Perceived economic benefits were found to be the main factor influencing consumers to purchase electric two-wheelers. The findings of this research also show that women are more inclined towards purchasing electric two-wheelers than men. These results offer useful information for governments and electric-two-wheelers companies to gain a better understanding of consumer behavior towards purchasing electric two-wheelers.
\end{abstract}

Keywords: electric vehicles; electric two-wheelers; electric motorcycle; green consumption behavior; behavioral intention; attitude; TPB; PLS-SEM

\section{Introduction}

The demand for electric vehicles (EVs) has significantly increased in recent years, representing only a small percentage of the total new vehicles sold globally. Electric vehicles (EVs) are revolutionizing the world of road transport, but it is at a nascent stage in India. In 2020, global eclectic car sales touched 10 million, but it represented only $1 \%$ of overall sales [1]. Electric two-wheelers (E2W) occupy the largest EV type with 25 million in 2020, mainly due to increased demand in Asian countries [2]. Asia is the biggest market for electric two-wheelers due to developing economies such as India, China, and Japan. India's automobile market is dominated by two-wheelers, and more than $80 \%$ of automobile sales in India comes from two-wheelers [3]. The Indian government targets suggest that 30\% of all vehicles sold in India by 2030 will be electric to reduce air pollution. According to SIAM, 15,119,387 two-wheelers were sold in the year 2020-2021 in India, and out of these, 143,837 units were electric two-wheelers [4]. In 2021, the total sales of electric two-wheelers were less than $1 \%$ only [5]. The adoption of electric two-wheelers (E2W) is very low in India despite various government initiatives. The EV two-wheelers adoption rate in India is down due to high upfront costs, range anxiety, inadequate charging stations, and battery replacement costs [6].

India is ranked as the third most polluted country in the world and received 22 of the 30 most polluted cities [7]. The air pollution is caused due to components like nitrogen, sulphur, carbon monoxide, carbon dioxide, dust, and ash. India is the third 
largest emitter of carbon dioxide, which is one of the major causes for air pollution [8]. India's transport sector is the third most $\mathrm{CO}_{2}$-emitting sector [9]. The MOSPI reports estimates that transportation sector contributes nearly $7.5 \%$ of the overall carbon dioxide emissions in India [10]. In this context, the shift to electric mobility has become inevitable to reduce greenhouse gas (GHG) emissions as EVs emit $50 \%$ fewer greenhouse gases than petrol or diesel [6]. EV adoption is, therefore, the best solution to tackle the hazardous air pollution levels in choked cities in India. There are different categories of electric vehicles, including battery EV, hybrid EV, plug-in hybrid EV, extended-range EV, and fuel cell EV. Electric two-wheelers mostly operate with the help of battery-run electric motors. The electric two-wheeler category comprises of bicycles, mopeds, scooters, and motorcycles. Electric bicycles are commonly called electric bikes or e-bikes. The maximum speed is below $20 \mathrm{MPH}$. Electric scooters and motorcycles are commonly used in India. Electric two-wheelers use a lead-acid or lithium-ion battery. In 2021, Hero Electric and Okinawa E2W continue to lead the Indian market, accounting for over $50 \%$ of the total sales [11]. Electric two-wheelers are more suitable for developing countries like India as they can use a portable battery, which can be recharged via a standard wall outlet from a home or office.

Electric vehicles have gained popularity as an eco-friendly alternative to petrolpowered vehicles owing to their zero carbon emissions. Compared to petrol-run twowheelers, electric two-wheelers are highly efficient, with less pollution and low noise levels. However, the usage of electric motorcycles is still in the initial stage, and customer acceptance of this new product still requires further research. The major problem of electric vehicles is their high cost of the battery, short driving range due to limited charging capacity, and a long recharging time [12]. A good number of research articles have been published related to consumer adoption of electric cars [13,14] and hybrid cars (e.g., [15]). Still, limited studies have been published related to the adoption of electric two-wheelers. Most of the previous research related to the adoption of electric cars, but very few studies were done on the electric two-wheelers. The acceptance of electric vehicles has been found to differ across different geographical and economic conditions [10]. The purpose of this research was to develop an adoption model for electric two-wheelers. This research identified the factors that determine the intention to purchase electric two-wheelers from the literature review. The proposed model can be used to formulate suitable policies to speed up the purchase of electric two-wheelers. The proposed model can also be used to guide the companies selling electric two-wheelers. The government's promoting the acceptance of EV will reduce pollution and the country's oil import.

The reminder of this article is organized as follows. Section 2 outlines the major electric vehicle adoption research conducted and critically reviewed their findings. The Section 3 presents the conceptual framework of the research, and the research methodology is presented in Section 4. The data analysis and inference are presented in Section 5, and Section 6 highlights the conclusion and limitation of the research with direction for future research being mentioned.

\section{Literature Review}

Electric vehicle (EV) adoption is one of the widely researched topics at present, and a good number of studies have been done on electric vehicle adoption [16]. Potential electric vehicle purchasers view the higher cost, limited driving range, and time taken to recharge the battery as disadvantages compared to conventional vehicles $[17,18]$. Many previous studies on EV revealed that consumers' adoption depends on psychological factors like attitudes, environmental concern, awareness, symbolism, self-identity, emotional responses, and diffusion of innovation [19]. Habich-Sobiegalla et al. (2018) developed the research framework using both micro-level, macro-level, and product-level factors that influence purchase intention [20]. Most of the previous research studies included socio-demographic characteristics and micro-, macro-, and product-level factors that affect intention to adopt EV [20]. Some of the socio-demographic variables included in their study were age, gender, education, and environmental concerns. Habich-Sobiegalla et al. 
(2018) surveyed 2806 participants from China, Brazil, and Russia. Their research findings show that micro-level factors like personal factors were less important than macro-level and product-level factors. Macro-level factors include EV charging infrastructure and government policy incentives. The battery life, purchase cost, driving range, and charging times were considered product-level factors [20]. Higueras-Castillo et al. (2021) studied product factors like minimum range, charging time, low noise, acceleration, and context factors like price, perceived benefit, incentives, and infrastructure [21]. Higueras-Castillo et al. (2021) surveyed 404 prospective EV consumers in Spain about their beliefs, EV attitudes, and purchase intention towards EVs [21]. Their research findings reveal that driving range, government incentives, and reliability are the most important predictors of purchase intention.

An electric vehicle is considered as a new product with green technology; therefore, its consumer buying behavior is innovative. Some researchers adopted technology acceptance theories like TPB, TAM, UTAUT, and DoI to understand the consumer adoption of the electric vehicle. One of the popular theories used to study the adoption of EV is Ajzen's (1985) theory of planned behavior (TPB) [22], which is an extension of Fishbein's (1977) theory of reasoned action (TRA) [23]. Ajzen's theory of planned behavior (TPB) proposes that human decision-making is based on rational evaluations. The theory explains that subjective norms, attitudes toward behavior, and perceived behavioral control can predict behavior intention [22]. Consumer behavioral intention measures the willingness to engage in purchasing behavior. Green consumer behavior is more frequently studied using TPB [24]. Another popular theory used to study behavioral intention is the technology acceptance model (TAM), which was proposed by Davis in 1989 [25]. The TAM considers perceived usefulness and perceived ease of use to influence the user attitude and behavioral intention. Habich-Sobiegalla et al. (2020) used frameworks for a systematic classification of factors that drive or motivate consumers' purchase of electric vehicles. Few researchers used Rogers's (2003) diffusion of innovation theory (DoI) to study EV adoption behavior [26]. Khazaei and Tareq (2021) used an extended unified theory of acceptance and the use of technology (UTAUT2) model [27] to examine consumers' acceptance of electric vehicles in Malaysia [28].

Prior research findings presented in the literature review show that many factors determine consumers buying of electric vehicles [21]. Some of the factors are environmental concern, perceived economic benefits, attitude, charging infrastructure, government incentives ([29]), environmental awareness, cost of ownership [30], etc. Asadi et al. (2020) developed a research model using the norm activation model (NAM) and the theory of planned behavior to study the intention to buy electric vehicles in Malaysia [31]. Their research findings showed that perceived value, attitude, perceived consumer effectiveness, subjective norms, and awareness of outcomes significantly affect consumers' electric vehicles' adoption intention. Lashari et al.'s (2021) study in South Korea showed that attributes related to attitude and perceptions related to the environment and economic benefits of using EV significantly affected the EV intention to purchase [16]. Wang and Zhou (2016) used rational choice theory (RCT) to understand the consumers' intention to purchase electric vehicles in China [32]. Their research findings showed the willingness to purchase electric vehicles depends on charging infrastructure, financial incentives, environmental awareness, and social influence [32].

There is limited research done on electric two-wheelers. Asians prefer to buy motorcycles to cars because they are relatively cheap, have low fuel consumption, and have low operational costs [33,34]. Will et al. (2021) surveyed 432 European participants to understand the intention to buy an electric two-wheeler [18]. The research findings showed that riding experience, easy parking, and low maintenance costs are the main reasons. Guerra (2017) surveyed 1200 respondents in Indonesia to find the consumers' intention to purchase electric motorcycles [35]. Survey respondents were given five-choice scenarios like price, driving range, speed, and charge time; the research finding showed that $26 \%$ prefer to buy an electric motorcycle. According to Kumar (2020) [3], 50\% of participants 
mentioned in the survey that the main reason for opting for an electric vehicle was due to cost-effectiveness. Chen et al. (2017) surveyed 233 respondents in Taiwan to study purchase intentions to buy hydrogen-electric motorcycles [36]. Their research findings showed that perceived quality, product knowledge, and perceived value positively influence purchase intentions.

Mamun et al. (2020) studied consumers' intention to buy electric scooters using TPB in Malaysia [37]. The study findings show that concern for the environment affects attitude towards electric scooters positively and significantly. Their research also shows that subjective norms, attitudes, perceived behavioral control, and monetary benefit significantly affect the intention to purchase an electric scooter. According to Utami et al. (2020), charging station infrastructure availability at the workplace, charging station infrastructure availability at home, the purchase incentive policy, and the charging cost discount significantly influence the intention of adopting an electric motorcycle [38]. The list of major research articles on electric vehicles is presented in Table 1.

Table 1. Review of the electric vehicle intention to purchase studies.

\begin{tabular}{|c|c|c|c|c|}
\hline Authors (Year) & Type of EV & Major Theories & Major Constructs & Country/Region \\
\hline $\begin{array}{l}\text { Khazaei and Tareq } \\
\text { (2021) [28] }\end{array}$ & EV & UTAUT2 & $\begin{array}{l}\text { Social influence, facilitating conditions, range } \\
\text { anxiety, and perceived enjoyment }\end{array}$ & Malaysia \\
\hline $\begin{array}{l}\text { Will, Luger-Bazinger, } \\
\text { Schmitt, and Zankl, } \\
2021[18]\end{array}$ & $\begin{array}{l}\text { Electric } \\
\text { two-Wheeler }\end{array}$ & - & Mobility patterns, range, and trip purpose & Europe \\
\hline $\begin{array}{l}\text { Malik and Yadav, } 2021 \\
\text { [39] }\end{array}$ & EV & TRA, TPB & $\begin{array}{c}\text { Past green behavior, environmental concern, } \\
\text { social influence, consumer environmental } \\
\text { attitude, awareness of EVs, attitude, } \\
\text { perceived economic benefit, } \\
\text { purchase intention }\end{array}$ & India \\
\hline Javid et al. 2021 [40] & EV & $\begin{array}{l}\text { Norm activation } \\
\text { model (NAM) }\end{array}$ & $\begin{array}{l}\text { Reliable factors, awareness of consequences, } \\
\text { description of responsibility, social values, } \\
\text { personal preferences, economic values, } \\
\text { willingness to buy and willingness to use and } \\
\text { personal norms }\end{array}$ & Pakistan \\
\hline $\begin{array}{l}\text { Mamun, Zainol, and } \\
\text { Hayat, } 2020 \text { [37] }\end{array}$ & Electric scooter & ТPB & $\begin{array}{c}\text { Environmental concern, knowledge of } \\
\text { environment, attributes of interest, attitude, } \\
\text { subjective norms, PBC, and perceived } \\
\text { monetary benefit }\end{array}$ & Malaysia \\
\hline Asadi et al., 2020 [31] & EV & TPB, NAM & $\begin{array}{l}\text { Perceived value, attitude, perceived } \\
\text { behavioral control, subjective norm, personal } \\
\text { norm, perceived consumer effectiveness, } \\
\text { financial incentives, purchase intention }\end{array}$ & Malaysia \\
\hline Elena et al., 2020 [21] & EV & - & $\begin{array}{l}\text { Product factors like driving range, time taken } \\
\text { to charge, low noise, speed, and context } \\
\text { factors such as: perceived benefit, price, } \\
\text { incentives, and infrastructure. }\end{array}$ & Spain \\
\hline Tu and Yang, 2019 [41] & EV & TA, TPB, IDT & $\begin{array}{l}\text { Attitude, subjective norm, self-control ability, } \\
\text { and purchase intention }\end{array}$ & China \\
\hline Xu et al. 2019 [42] & EV & ТРB & $\begin{array}{l}\text { Attitude, PBC, subject norms, environmental } \\
\text { performance, price value, non-monetary } \\
\text { incentives, monetary incentives }\end{array}$ & China \\
\hline $\begin{array}{l}\text { Wang and Zhou, } 2019 \\
\text { [32] }\end{array}$ & $\mathrm{EV}$ & $\mathrm{RCT}$ & $\begin{array}{l}\text { Charging infrastructure, purchase cost, } \\
\text { driving range, government financial } \\
\text { incentives, individual environmental } \\
\text { awareness, and perceived social influence. }\end{array}$ & China \\
\hline
\end{tabular}


Table 1. Cont.

\begin{tabular}{ccccc}
\hline Authors (Year) & Type of EV & Major Theories & Major Constructs & Country/Region \\
\hline $\begin{array}{c}\text { Habich-Sobiegalla, } \\
\text { Kostka, and Anzinger, } \\
\text { 2018 [20] }\end{array}$ & EV & - & $\begin{array}{c}\text { Environmental concern, EV experience, policy } \\
\text { incentives, infrastructure readiness, purchase } \\
\text { cost, and technological readiness }\end{array}$ & $\begin{array}{c}\text { China, Russia, } \\
\text { and Brazil }\end{array}$ \\
\hline $\begin{array}{c}\text { Chen, Tsai, and Hsieh, } \\
\text { 2017 [36] }\end{array}$ & $\begin{array}{c}\text { Hydrogen- } \\
\text { electric } \\
\text { motorcycles }\end{array}$ & TAM & $\begin{array}{c}\text { Product knowledge, perceived risk, perceived } \\
\text { quality, purchase intention, and } \\
\text { perceived value }\end{array}$ & Taiwan \\
Wang et al., 2014 [15] & Hybrid EV & TPB & $\begin{array}{c}\text { Attitude, subjective norm, personal moral } \\
\text { norm, perceived behavioral control, and } \\
\text { concern for environment }\end{array}$ & China \\
\hline
\end{tabular}

\section{Conceptual Framework and Research Hypotheses}

The research framework for this research is based on the extended Theory of Planned Behaviour. The variables used in developing the framework were developed based on the literature review on the consumer adoption of electric vehicles. As presented in Table 1, a good number of researchers have used the TPB model to study the adoption of electric vehicles. Most of the previous studies focused only on the consumer's intention to purchase electric vehicles, but this study investigates the consumer intention to buy electric twowheelers. In this study, the environmental concern, perceived economic benefits, social influence, charging Infrastructure, and attitude affect the intention to purchase electric two-wheelers. A conceptual model is presented in Figure 1.

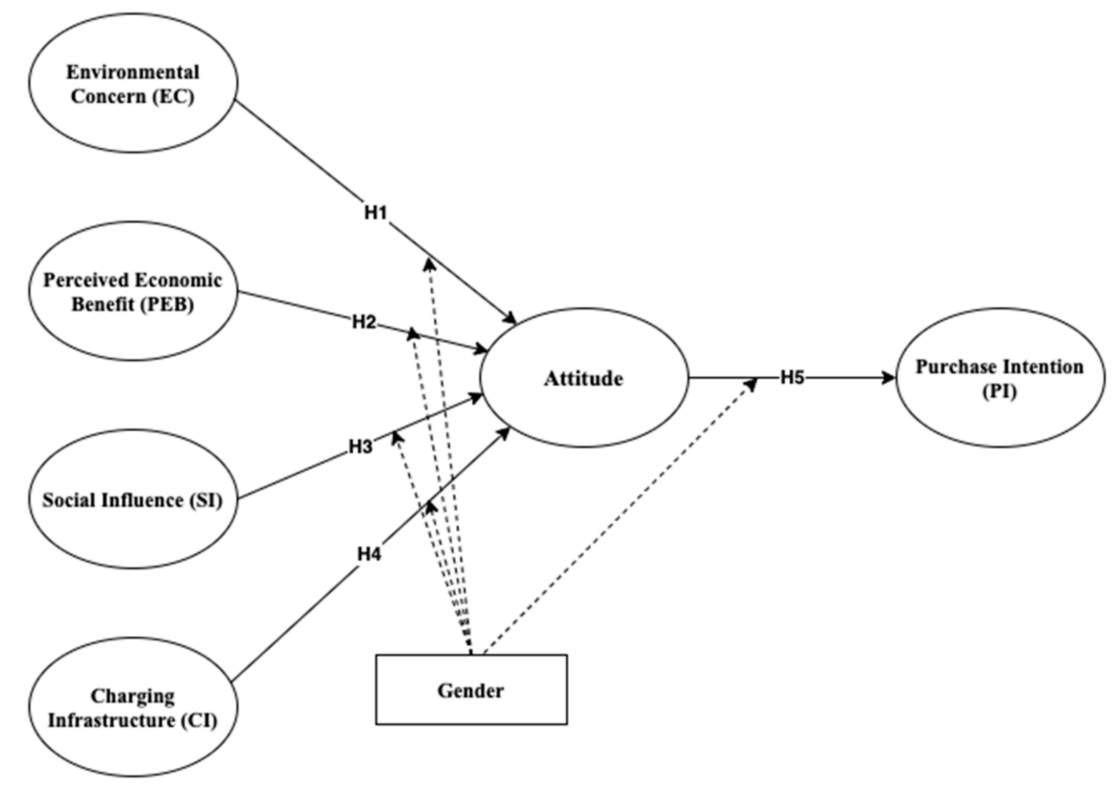

Figure 1. Conceptual model.

\subsection{Environmental Concern}

Many researchers have studied the relationship between concern for the environment and consumer buying behavior and found that higher environmental concern consumers are more likely to buy environmentally friendly products like electric two-wheelers [39]. Peters and Dütschke's (2014) research survey conducted in Germany shows that the environmental benefits of $\mathrm{EV}$ are one of the main motivators for the intention to buy EVs [43]. Wang et al.'s (2016) study in China showed that environmental concern indirectly affects the intention to adopt hybrid EVs and that attitude has a mediating effect [15]. Lai et al.'s (2015) study conducted in Macau also supports the finding that environmental concern influences the adoption of full-electric vehicles [44]. Based on previous research 
work, it is clear that consumers with great concern for the environment may consider buying environment-friendly products or green products like EVs [45]. Hence, this study hypothesized the following:

Hypotheses 1 (H1). Environmental concern positively affects the consumer's attitude towards electric two-wheelers.

\subsection{Perceived Economic Benefits}

Perceived benefits are the positive outcome of a product purchase [46], and they can be classified into financial (economic) and non-financial benefits [47]. Some of the economic benefits derived from buying electric two-wheelers are benefits from government subsidies, the low cost of maintenance, and zero fuel costs. The product purchase decision is often affected by consumers' perception of economic benefits. Lai et al.'s [44] study on intention towards full electric vehicles showed a significant relationship between perceived economic benefits and intention to buy EVs. Hence, this study hypothesized the following:

Hypotheses 2 (H2). Perceived economic benefit positively affects the consumer's attitude towards electric two-wheelers.

\subsection{Social Influence}

Social influence can be defined as other people like friends, family members, or peers, which can influence a consumer's individual decisions like product selection decisions [48]. The social influence construct covers social pressure, subjective norms, peer influence, and cultural influence. Certain consumers always seek social approval for buying and using a product. They will avoid buying products for which they think there is no social approval. Previous studies' findings show that social influence is an important factor that affects consumers' intention to buy electric vehicles [49]. Tu and Yang's (2019) research showed that subjective norms significantly impact EV purchase decisions [41]. Khazaei and Tareq's (2021) research in Malaysia showed that social approval is one of the important factors for consumers' adoption of battery electric vehicles [28]. Therefore, social influence may affect individuals' attitudes and intentions towards electric two-wheelers also as it is a new technology. Hence, this study hypothesized the following:

Hypotheses 3 (H3). Social influence positively affects the consumer's attitude towards electric two-wheelers.

\subsection{Charging Infrastructure}

Charging infrastructure is frequently mentioned as one of the major factor influencing electric vehicle adoption [26]. The main reason for this is there is a fear among consumers that EVs might run out of power between charging points. According to Tarei et al. (2021), using a survey of experts in India, infrastructural barriers were ranked first as the major barrier that inhibits the adoption of EV [10]. Charging infrastructure is often considered an important barrier to purchase electric vehicles. The electric vehicle charging infrastructure is less developed in India, with 26 EVs per charger [50]. Nair et al.'s (2017) research showed that insufficient charging infrastructure is the main barrier for EV adoption in India [51]. Charging infrastructure as the most important barrier to EV adoption is highlighted by researchers from other countries [10]. Previous research findings show that charging infrastructure availability will increase the intention to buy electric vehicles. Hence, this study hypothesized the following:

Hypotheses 4 (H4). Charging Infrastructure positively affects the consumer's attitude towards electric two-wheelers.

\subsection{Attitude and Purchase Intention}

Consumer purchase intentions and attitudes are widely studied and mentioned in many behavioral models like the theory of reasoned action (TRA), the theory of planned 
behavior (TPB), and the technology acceptance model (TAM). Yang et al. (2020) [47] and Wang et al. (2018) [52] showed that consumer attitude is positively related to the purchase intention of electric vehicles in China. Khurana et al. (2019) [53] also showed that attitude strongly influences the adoption of eclectic cars in India. In the present study, electric two-wheelers attitudes are believed to affect consumers' intention to purchase. Hence, this study hypothesized the following:

Hypotheses 5 (H5). Attitude positively affects the consumers' purchase intention of electric two-wheelers.

\subsection{Moderating Effects of Gender}

The relationship between gender and purchase intentions for EVs are widely studied, but somewhat inconsistent findings were presented by researchers around the world. The research related to EVs in Western countries shows that women tend to have higher purchase intentions [20]. Habich-Sobiegalla et al.'s (2018) research in Russia showed that women are more likely to purchase EVs than men [20], which was also supported by the research finding of She et al. (2017) conducted in China [54]. Research conducted by Tiwari et al. (2019) in the UK also showed that women are more inclined to the purchase of EVs. Chen et al.'s (2020) research on electric vehicle adoption in Nordic countries showed that men are more inclined to buy electric vehicles [55]. Including the gender as a moderating variable for this current study will better explain consumers' intention to buy electric two-wheelers. Based on the discussion above, the sixth hypothesis was framed.

Hypotheses 6 (H6). Gender moderates the relationship between environmental concern, perceived economic benefit, social influence, charging infrastructure, attitude, and purchase intention toward electric two-wheelers.

The present empirical study purposed to develop an adoption model for electric two-wheelers identified meaningful determinants, namely, environmental concern (EC), perceived economic benefits (PEB), social influence (SI), charging Infrastructure (CI), the attitude of consumers (ATT), and purchase intention (PI) of consumers from a review of the literature. These six determinants in the model had four, four, five, four, five, and three items, respectively. The conceptual model of the study is represented in Figure 1.

\section{Research Methodology}

\subsection{Data Collection and Sample Size}

The data collected for this research were primary data collected through online surveys to find the factors influencing the purchase of electric two-wheelers in India. The sampling procedure used for this research was the non-probability sampling procedure. The data for this research were collected using purposive sampling techniques, including one of the non-probability sampling techniques. Identifying all the potential two-wheeler buyers in India would be costly, challenging, and time-consuming; therefore, purposive sampling techniques for data collection from the respondents were used for this research. The questionnaire was developed by examining various adoption scales and metrics mentioned in the literature. The questionnaire was divided into two parts. Section A contained all personal data concerning participants, including the name, gender, age, education, family income, type of vehicle owned, and distance traveled. Section B includes awareness of EV, environmental concern, perceived economic benefits, social influence, charging infrastructure, attitude, and intention to buy. A five-point Likert scale was adopted for this research in which "strongly agree" was rated as 1 and "strongly disagree" was rated as 5.

The minimum sample size can be calculated using many methods. According to Hair et al. (2012), the first step to estimate the required sample size is to identify the construct in the model with the largest number of paths directed towards it [56]. Then, the minimum required sample size is equal to or greater than ten times the number of structural paths directed towards the identified construct [56]. Based on the proposed conceptual model, most paths are directed to the construct attitude in four paths. Thus, based on the approach 
mentioned above, 40 respondents were calculated as the minimum sample size for this study. The $G^{*}$ power sample size analysis program introduced by Faul was used to find the minimum required sample size [57] for this research. Cohen (1992) [58] has given the following recommendations: the effect size (f2) can be equal to 0.15 , the error type $(\alpha)$ can be equal to 0.05480 , and the error type $2(\beta)=0.20$. The $G^{*}$ power was run with the number of predictors for this study as five; the results show that the minimum recommended sample size for this research can be 89, as shown in Figure 2. Based on the $\mathrm{G}^{*}$ power analysis, the minimum sample size estimated was 89 respondents with a power of 0.95 , whereas the study used a sample size of 182 , satisfying the appropriate sample size requirements.

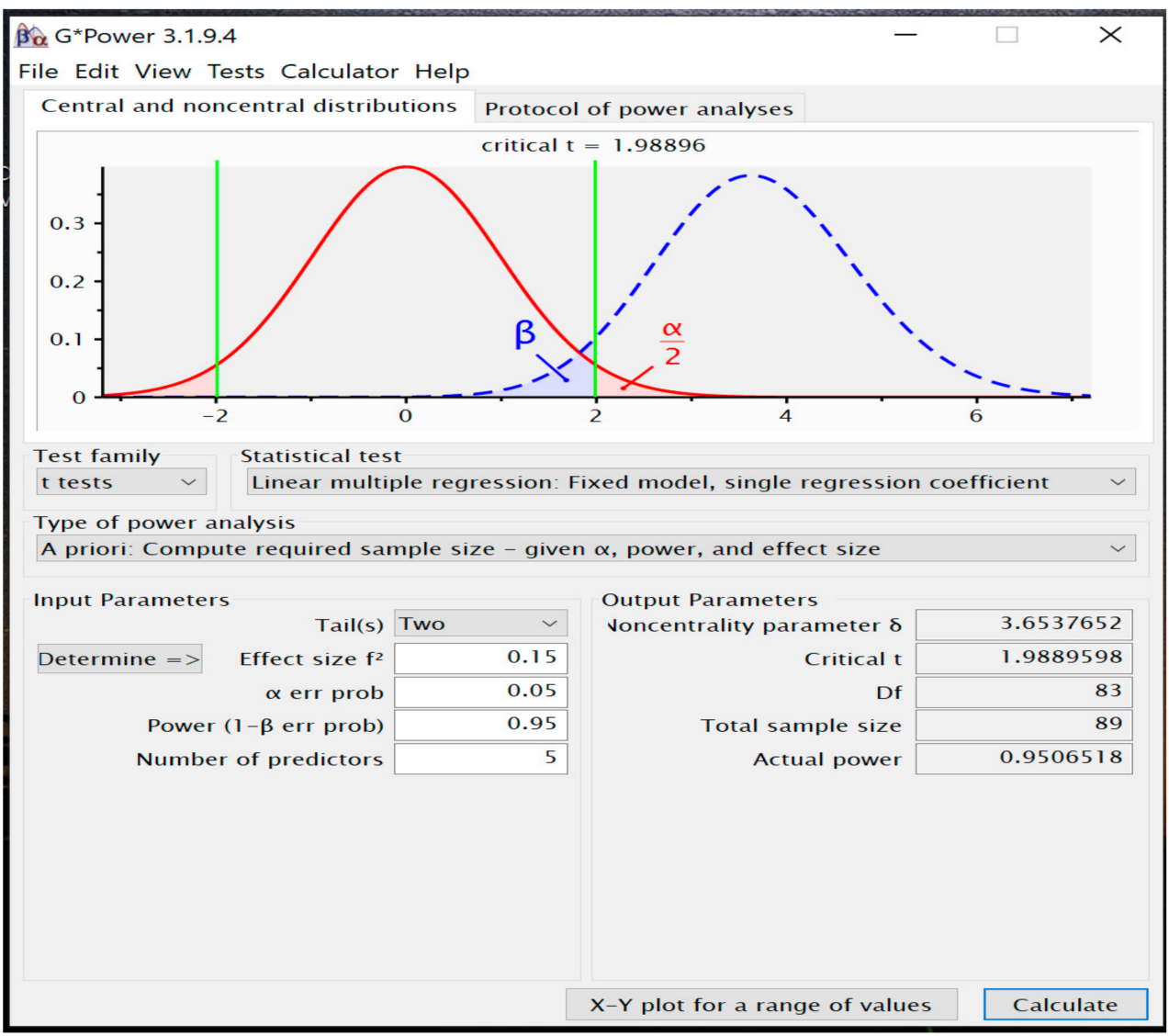

Figure 2. G*Power analysis.

\subsection{Development of the Questionnaire}

This research framework involved four constructs that affect directly or indirectly the attitude and intention to buy electric two-wheelers. The six constructs used for this research were environment concern, perceived economic benefits, social influence, charging infrastructure, attitude, and intention to buy. All the six constructs' measures were developed by referring to the item scales used by previous researchers to measure EV's intention to purchase. All constructs' questions were measured using a Likert scale with strongly agree rated as 1 and strongly disagree rated as 5 . The list of item scales used for this research and their sources are presented in Appendix A.

\subsection{Data Analysis Method}

The data analysis method used for this research was partial least squares structural equation modeling (PLS-SEM) using R software. PLS-SEM is a multivariate analysis method to find path models with latent constructs. It is one of the structural equation modeling methods that is widely applied in social science research [59]. The conceptual model needs to be tested to find whether the latent variable, i.e., the construct, has been 
measured through the items and to test the path that is the relationship between the constructs. The procedure involved in testing both the inner and outer model is called a two-step approach and was earlier suggested by Straub (1989) [60]. The first step involves evaluating the measurement model or outer model. The second step is judging the inner model that tests the relationship between the constructs using multiple regression.

PLS-SEM is a type of SEM that uses a causal-predictive approach. This SEM approach focuses on predicting when estimating statistical models with structures meant to provide causal explanations [61]. PLS-SEM is now widely accepted in many social science disciplines, including marketing management [56]. PLSEM is executed using R software. Applying a smaller sample size is undeniably utilized with PLS-SEM, but Hair also added that properties of the population decide when a smaller sample size is suitable [59].

\section{Data Analysis and Inference}

\subsection{Respondent Profile}

The data collected in this research were obtained through online surveys to find the factors influencing the purchase of two-wheelers in India. The questionnaire method was employed with a total of 250 questionnaires and was distributed from 5 May to 28 July 2021; 182 valid questionnaires were returned, yielding a $72.8 \%$ response rate. Table 2 illustrates the sample profile of the respondents in this study. The number of responses from female participants was slightly higher than male participants, and 81.3 percent of the sample represented the 21-30 years age group.

Table 2. Respondent's profile.

\begin{tabular}{|c|c|c|c|}
\hline \multicolumn{2}{|c|}{ Demographic Attributes } & \multirow{3}{*}{$\begin{array}{c}\text { Frequency } \\
83 \\
99\end{array}$} & \multirow{3}{*}{$\begin{array}{c}\text { Percentage } \\
45.6 \\
54.4\end{array}$} \\
\hline & Male & & \\
\hline Gender & Female & & \\
\hline \multirow{5}{*}{ Age } & $<20$ & 11 & 6.0 \\
\hline & $21-30$ & 148 & 81.3 \\
\hline & $31-40$ & 15 & 8.2 \\
\hline & $41-50$ & 5 & 2.7 \\
\hline & $>50$ & 3 & 1.6 \\
\hline \multirow{8}{*}{ Occupation } & Student & 121 & 66.5 \\
\hline & Private job & 25 & 13.7 \\
\hline & Government job & 9 & 4.9 \\
\hline & Business & 12 & 6.6 \\
\hline & Retired & 2 & 1.1 \\
\hline & Unemployed & 05 & 2.7 \\
\hline & Homemaker & 4 & 2.2 \\
\hline & Other & 4 & 2.2 \\
\hline \multirow{3}{*}{ Educational Qualification } & Highschool or below & 6 & 3.3 \\
\hline & Undergraduate & 72 & 57.1 \\
\hline & Postgraduate & 104 & 39.6 \\
\hline \multirow{5}{*}{ Monthly Family income } & $<$ INR 50,000 & 53 & 29.1 \\
\hline & INR 50,000-100,000 & 47 & 25.8 \\
\hline & INR 100,000-150,000 & 25 & 13.7 \\
\hline & INR 150,000-200,000 & 22 & 12.1 \\
\hline & >INR 200,000 & 35 & 19.2 \\
\hline
\end{tabular}

\subsection{Assessment of Measurement Model (Outer Model)}

The analysis for this study was performed by PLS-SEM using R. This research followed the two-step approaches of SEM recommended by Anderson and Gerbing (1988) [62]. The confirmatory factor analysis (CFA) was the first step of SEM data analysis, which involves examining the construct validity and the reliability of the measurement model. The second step involves analyzing the path effects and their significance on the structural model. 


\subsubsection{Convergent Validity and Reliability}

The measurement model convergent validity was obtained as it measures the construct validity as well. Convergent validity assesses whether the construct correlates with related variables but not unrelated constructs [63]. According to Hair [64], the factor loading of each item ideally should be above 0.5 and should be connected to their respective latent construct variable. In this study, one of the items of the charging infrastructure was found to have very little loading. As a latent variable can be estimated with a minimum of three items, the low loading item was removed from the variable [65]. The convergent validity of the constructs was checked by checking the average variance extracted (AVE) and the composite reliability (CR). The calculation of AVE and CR was done manually and presented in Table 3. Loadings above 0.708 are recommended, as this can be interpreted as more than 50 percent of the indicator's variance as explained by the construct, and it provides a value that is the acceptable item reliability [66]. The loading of all the items was above 0.708, except for PEB1. The internal reliability for all item scales of each construct was investigated through Cronbach's alpha and the composite reliability (CR). The Cronbach's alpha and the composite reliability (CR) need to be above the threshold limit of $0.70[66,67]$. The Cronbach's alpha for the PEB1 construct was below the value of 0.70 ; however, the value of the composite reliability (CR) was sufficiently above the limit of 0.70 to establish the reliability of the constructs [59].

Table 3. The reliability and validity results for the constructs.

\begin{tabular}{|c|c|c|c|c|c|c|c|}
\hline Construct & Items & $\begin{array}{l}\text { Loadings/ } \\
\text { Weights }\end{array}$ & $\begin{array}{c}\text { Cronbach's } \\
\text { Alpha }\end{array}$ & Eig. 1st & Eig. 2nd & CR & AVE \\
\hline \multirow{4}{*}{$\begin{array}{l}\text { Environmental } \\
\text { concern (EC) }\end{array}$} & EC1 & 0.880 & \multirow{4}{*}{0.863} & \multirow{4}{*}{2.83} & \multirow{4}{*}{0.46} & \multirow{4}{*}{0.906} & \multirow{4}{*}{0.706} \\
\hline & $\mathrm{EC} 2$ & 0.860 & & & & & \\
\hline & EC3 & 0.815 & & & & & \\
\hline & EC4 & 0.805 & & & & & \\
\hline \multirow{4}{*}{$\begin{array}{c}\text { Perceived } \\
\text { economic benefit } \\
(\mathrm{PEB})\end{array}$} & PEB1 & 0.657 & \multirow{4}{*}{0.785} & \multirow{4}{*}{2.44} & \multirow{4}{*}{0.71} & \multirow{4}{*}{0.858} & \multirow{4}{*}{0.604} \\
\hline & PEB2 & 0.883 & & & & & \\
\hline & PEB3 & 0.757 & & & & & \\
\hline & PEB4 & 0.794 & & & & & \\
\hline \multirow{4}{*}{$\begin{array}{l}\text { Social influence } \\
\text { (SI) }\end{array}$} & SI1 & 0.880 & \multirow{4}{*}{0.876} & \multirow{4}{*}{2.92} & \multirow{4}{*}{0.55} & \multirow{4}{*}{0.915} & \multirow{4}{*}{0.729} \\
\hline & SI2 & 0.860 & & & & & \\
\hline & SI3 & 0.815 & & & & & \\
\hline & SI4 & 0.805 & & & & & \\
\hline \multirow{4}{*}{$\begin{array}{c}\text { Charging } \\
\text { infrastructure } \\
(\mathrm{CI})\end{array}$} & CI1 & 0.657 & \multirow{4}{*}{0.860} & \multirow{4}{*}{2.82} & \multirow{4}{*}{0.49} & \multirow{4}{*}{0.905} & \multirow{4}{*}{0.704} \\
\hline & $\mathrm{CI} 3$ & 0.883 & & & & & \\
\hline & CI4 & 0.757 & & & & & \\
\hline & CI5 & 0.794 & & & & & \\
\hline \multirow{5}{*}{ Attitude (ATT) } & ATT1 & 0.880 & \multirow{5}{*}{0.902} & \multirow{5}{*}{3.59} & \multirow{5}{*}{0.48} & \multirow{5}{*}{0.927} & \multirow{5}{*}{0.718} \\
\hline & ATT 2 & 0.860 & & & & & \\
\hline & ATT 3 & 0.815 & & & & & \\
\hline & ATT 4 & 0.805 & & & & & \\
\hline & ATT 5 & 0.657 & & & & & \\
\hline \multirow{3}{*}{$\begin{array}{c}\text { Consumer } \\
\text { purchase } \\
\text { intention (PUIN) }\end{array}$} & PUIN1 & 0.914 & \multirow{3}{*}{0.881} & \multirow{3}{*}{2.43} & & & \\
\hline & PUIN2 & 0.913 & & & 0.38 & 0.927 & 0.808 \\
\hline & PUIN3 & 0.869 & & & & & \\
\hline
\end{tabular}

Unidimensionality explains whether measurement items reflect only one construct [68]. The factor or latent variable is unidimensional if the first eigenvalue is higher than 1 and the second eigenvalue is less than 1 [69]. It appears that the latent variables EC, SI, CI, PEB, ATT, and PUIN met this criterion. The analyses also show that the average variance extracted (AVE) exceeded the acceptable thresholds of 0.5 [70]. 


\subsubsection{Discriminant Validity}

Discriminant validity is part of construct validity [71]. Discriminant validity explains how one latent variable discriminates from another latent variable [72]. Discriminant validity is evaluated with the help of Fornell and Larcker's criterion [70], whereby the under-the-root of AVEs 0.840, 0.854, 0.839, 0.777, 0.847, and 0.899 was higher than their inter-item correlation values. Table 4 shows the discriminant validity of the constructs, and it explains that each construct had a clear distinction from others, thus establishing the outer model fit. Discriminant validity can also be calculated by comparing the loading for each measurement item and the cross-loading of other items [73]. The comparison results show that the items loaded on their respective latent variable were higher than the cross-loading of other items.

Table 4. Discriminant validity using Fornell and Larcker's criteria.

\begin{tabular}{ccccccc}
\hline & EC & PEB & SI & CI & ATT & PUIN \\
\hline EC & 0.840 & & & & & \\
\hline PEB & 0.464 & 0.777 & & & & \\
\hline SI & 0.462 & 0.642 & 0.854 & & & \\
\hline CI & 0.242 & 0.484 & 0.503 & 0.839 & & \\
\hline ATT & 0.449 & 0.547 & 0.539 & 0.458 & 0.847 & \\
\hline PUIN & 0.42 & 0.513 & 0.531 & 0.389 & 0.764 & 0.899 \\
\hline
\end{tabular}

\subsection{Inner Structural Model Analysis}

The measurement model of the conceptual model was found to be reliable and valid. The next step was to measure the inner structural model outcomes. The present study evaluated the inner structural model using the goodness-of-fit (GoF) index, the coefficient of determination $\left(\mathrm{R}^{2}\right)$, and the path coefficient. The overall goodness-of-fit $(\mathrm{GoF})$ of the model is one of the important steps in assessing the model in PLS-SEM. In PLS-SEM, the model fit can be assessed using inference statistics or model fit indices [74]. The model fit index is presented in Table 5.

Table 5. Model fit index.

\begin{tabular}{ccc}
\hline Name of Index & Model Fit of Research Model & Level of Acceptance \\
\hline Normed chi-square & 1.744 & CMIN $<3$ \\
SRMR & 0.061 & $<0.08$ \\
NFI & 0.859 & $>0.90$ \\
GFI & 0.851 & GFI $>0.8$ \\
Global GoF & 0.594 & $>0.36$ \\
\hline
\end{tabular}

The present study used the following fit measures: standardized root mean square (SRMR), the normed fit index (NFI), GoF, and $\mathrm{Chi}^{2}$ to analyze the overall goodness-of-fit. An SRMR value of less than 0.08 was considered adequate for PLS path models [74]. The present study's SRMR value was 0.061 , which was within the acceptable limit; therefore, we can consider the conceptual model as model fit. The calculated global GoF for this study was 0.594 , which was higher than threshold of GoF $>0.36$ recommended by Wetzels et al. (2009) [75].

The coefficient of determination $\left(R^{2}\right)$ measures the model's predictive accuracy, whose effect ranges from 0 to 1 [76]. According to Hair et al. (2014), an $R^{2}$ value above 0.75 is interpreted that the model exhibits substantial predictive accuracy. A value between 0.5 to 0.75 is considered a moderate level of predictive accuracy, and a value less than 0.5 is considered a weak level of predictive accuracy [76]. The inner path model of the present study's $\mathrm{R}^{2}$ was 0.734 ; therefore, the model exhibited moderate levels of predictive accuracy. This indicates that the five constructs moderately explain $73.4 \%$ of the variance. 


\section{Path Analysis}

The proposed conceptual model was evaluated by running PLS-SEM using $\mathrm{R}$ to test the five research hypotheses empirically. The PLS-SEM analysis was performed to test the research hypothesis empirically. The results suggest that the final model provides an acceptable fit, and all hypotheses were valid. As shown in Table 6, EC, PEB, SI, and CI have a marked effect on attitude, and attitude exerted an effect on purchase intention. Table 6 presents the results of bootstrap validation of the structural model. The charging infrastructure $t$ value was 2.89 with a 0.004 significant $p$ value, which shows that it is the major factor influencing the attitude towards electric two-wheelers.

Table 6. Results of bootstrap validation of the structural model.

\begin{tabular}{|c|c|c|c|c|c|c|c|c|c|}
\hline Hypothesis & Path & $\begin{array}{c}\text { Original } \\
\text { Path } \beta\end{array}$ & $\begin{array}{c}\text { Mean } \\
\text { Boot }\end{array}$ & Std. Error & perc. 025 & perc.975 & t-Statistics & $p$ Values & Results \\
\hline H1 & $\mathrm{EC} \rightarrow \mathrm{ATT}$ & 0.203 & 0.201 & 0.067 & 0.0332 & 0.362 & 0.303 & $0.003^{* *}$ & Accepted \\
\hline $\mathrm{H} 2$ & $\mathrm{PEB} \rightarrow \mathrm{ATT}$ & 0.229 & 0.242 & 0.0799 & 0.048 & 0.448 & 0.287 & $0.005^{* *}$ & Accepted \\
\hline $\mathrm{H} 3$ & $\mathrm{SI} \rightarrow \mathrm{ATT}$ & 0.198 & 0.192 & 0.0808 & -0.0447 & 0.414 & 2.450 & 0.015 * & Accepted \\
\hline $\mathrm{H} 4$ & $\mathrm{CI} \rightarrow \mathrm{ATT}$ & 0.199 & 0.201 & 0.0687 & 0.0118 & 0.38 & 2.890 & $0.004^{* *}$ & Accepted \\
\hline H5 & $\mathrm{ATT} \rightarrow \mathrm{PUIN}$ & 0.764 & 0.764 & 0.0342 & 0.6908 & 0.825 & 15.900 & $0.000^{* *}$ & Accepted \\
\hline
\end{tabular}

\subsection{Mediation Effect of Attitude}

This research attempted to find whether consumer attitude mediates the relationship between independent variables and purchase intention (DV), and the output is given in Table 7 . The effect of environmental concern on purchase intention mediated via attitude towards electric two-wheelers was evaluated. The relationship between environmental concern and attitude $(\beta=0.496, p<0.01)$ and between attitude and purchase intention ( $\beta=0.841, p<0.01)$ was significant. Whereas for environmental concern on purchase intentions, the direct effect $(\beta=0.126, p>0.05)$ was insignificant. The indirect effect of environmental concern on purchase intention was tested using bootstrapping procedures. Unstandardized indirect effects were computed for each 5000 bootstrapped sample. The bootstrapped unstandardized indirect effect was 0.417 , and the $95 \%$ confidence interval ranged from 0.260 to 0.596 . This provided evidence that attitude mediates the relationship of environmental concern and purchase intention. The results of mediation with effect size and the Sobel test are given in Table 7.

Table 7. Mediation effect.

\begin{tabular}{cccccccc}
\hline \multirow{2}{*}{$\begin{array}{c}\text { Independent } \\
\text { Variable }\end{array}$} & \multirow{2}{*}{ Mediator } & $\begin{array}{c}\text { Dependent } \\
\text { Variable }\end{array}$ & \multicolumn{2}{c}{ Direct Effect $\left(\mathbf{c}^{\prime}\right)$} & \multicolumn{3}{c}{ Indirect Effect (c) } \\
\cline { 5 - 8 } & & $\beta_{\mathbf{c}^{\prime}}$ & $\boldsymbol{\beta}_{\mathbf{c}}$ & Boot LLCI & Boot ULCI & Sobel Test \\
\hline EC & & 0.126 & $0.417^{* *}$ & 0.260 & 0.596 & $5.895^{* *}$ \\
PEB & \multirow{2}{*}{ Attitude } & Purchase & $0.161^{*}$ & $0.485^{* *}$ & 0.328 & $0.671^{* *}$ & $7.05^{* *}$ \\
SI & & intension & $0.181^{* *}$ & $0.388^{* *}$ & 0.263 & 0.535 & $6.95^{* *}$ \\
CI & & 0.049 & $0.309^{* *}$ & 0.208 & 0.413 & $6.13^{* *}$ \\
\hline
\end{tabular}

${ }^{* *} \operatorname{sig} p<0.01 .{ }^{*} \operatorname{sig}<0.05$.

The effect of perceived economic benefit on purchase intention mediated via attitude towards electric two-wheelers was evaluated. The relationship between perceived economic benefit and attitude $(\beta=0.597, p<0.01)$ and attitude and purchase intention ( $\beta=0.812, p<0.01)$ was significant. The direct effect $(\beta=0.161, p>0.01)$ was not significant. The indirect effect between perceived economic benefit on purchase intention was tested using bootstrapping procedures. Unstandardized indirect effects were computed for each 5000 bootstrapped sample. The bootstrapped unstandardized indirect effect was 0.485 , and the $95 \%$ confidence interval ranged from 0.328 to 0.671 . This provided evidence 
that attitude mediates the relationship between perceived economic benefit and purchase intention. The results of mediation and the Sobel test are given in Table 7.

The Effect of social influence on purchase intention was mediated via attitude towards electric two-wheelers was evaluated. The relationship between social influence and attitude ( $\beta=0.597, p<0.01)$, attitude, and purchase intention $(\beta=0.812, p<0.01)$ was significant. Whereas social influence on purchase intentions, the direct Effect $(\beta=0.161, p>0.01)$ was insignificant. The Indirect Effect of social influence on purchase intention was tested using bootstrapping procedures. Unstandardized indirect effects were computed for each 5000 bootstrapped sample. The bootstrapped unstandardized indirect Effect was 0.485, and the $95 \%$ confidence interval ranged from 0.328 to 0.671 . This provided evidence that attitude mediates the relationship between social influence and purchase intention. The results of the mediation and the Sobel test are given in Table 7.

The effect of charging infrastructure on purchase intention mediated via attitude towards electric two-wheelers was evaluated. The relationship between charging infrastructure and attitude $(\beta=0.359, p<0.01)$ and attitude and purchase intention $(\beta=0.861$, $p<0.01$ ) was significant. Whereas, for the relation between charging infrastructure on purchase intentions, the direct effect $(\beta=0.049, p>0.01$ ) was not significant. The indirect effect between charging infrastructure on purchase intention was tested using bootstrapping procedures. Unstandardized indirect effects were computed for each 5000 bootstrapped sample. The bootstrapped unstandardized indirect effect was $0.309(p<0.01)$, and the $95 \%$ confidence interval ranged from 0.208 to 0.413 . This provided evidence that attitude mediates the relationship between charging infrastructure and purchase intention. The results of the mediation and the Sobel test are given in Table 7.

\subsection{Moderating Effect of Gender}

The role of the moderating effect of gender on the relationship of EC, SI, CI, and PEB on Att was investigated by applying multigroup analysis using the pls-sem.group function in R with a bootstrap size of 2000 as recommended by Sarstedt et al. (2011) [77]. The results are presented in Table 8 . The results presented in the table show that, as the effect of EC and SI towards ATT were concerned, gender does not act as moderator. However, where the effect of CI towards ATT and PEB towards ATT are concerned, the $p$ value was $<0.05$, which gives an indication that the charging infrastructure and the perceived economic benefit have different effects towards the attitude between male and female.

Table 8. Moderating role of gender towards purchase intention mediated through attitude.

\begin{tabular}{|c|c|c|c|c|c|c|c|}
\hline Path & Total & $\beta_{\text {Male }}$ & B $_{\text {Female }}$ & Abs. Diff & t-Statistics & $p$ Value & Results \\
\hline $\mathrm{EC} \rightarrow \mathrm{ATT} \rightarrow \mathrm{PUIN}$ & 0.7231 & 0.6892 & 0.7693 & 0.0801 & 0.9216 & 0.179 & Rejected \\
\hline $\mathrm{PEB} \rightarrow \mathrm{ATT} \rightarrow \mathrm{PUIN}$ & 0.6873 & 0.5868 & 0.7689 & 0.1821 & 1.7282 & $0.0428 *$ & Accepted \\
\hline $\mathrm{SI} \rightarrow \mathrm{ATT} \rightarrow \mathrm{PUIN}$ & 0.6745 & 0.6121 & 0.7733 & 0.1612 & 1.5684 & 0.0593 & Rejected \\
\hline $\mathrm{CI} \rightarrow \mathrm{ATT} \rightarrow \mathrm{PUIN}$ & 0.7448 & 0.6436 & 0.8231 & 0.1795 & 1.6562 & 0.0497 * & Accepted \\
\hline
\end{tabular}

${ }^{*} \operatorname{sig}<0.05$.

The beta coefficient value of charging infrastructure on attitude was higher for males compared to females $(0.5837>0.3246)$; similarly, the beta value for perceived economic benefit was also higher for males compared to females. This indicates that where the effect of charging infrastructure and perceived economic benefits are concerned, gender acts as a moderator on the relationship towards attitude. Males are more influenced by the effect of charging infrastructure and perceived economic benefit compared to females.

\subsection{Result and Discussion}

This research used PLS-SEM to identify the factors that influence the consumer's intention to purchase electric two-wheelers. The results of the empirical analysis have shown some important findings, which are discussed as follows. 
Hypothesis 1 was accepted as the $p$-value was less than 0.05 , which means that environmental concern (EC) positively affects $(\beta=0.203)$ consumers' attitudes (ATT) towards electric two-wheelers. The relationship was significant both by bootstrapping $(0.033,0.362)$ and at a $1 \%$ level of significance. This indicates that if the consumers were more concerned about the environment, their attitude towards electric two-wheelers will be high. This is also supported by the previous research findings of Wang et al. (2016) [15] for electric vehicles and Mamun et al. (2020) on electric scooters.

Hypothesis 2 was accepted as the $p$-value was less than 0.05 , which means that the perceived economic benefit (PEB) positively affects $(\beta=0.229)$ consumers' attitudes (ATT) towards electric two-wheelers. The relationship was significant both by bootstrapping $(0.048,0.448)$ and at a $1 \%$ level of significance. This indicates that if the economic benefits perceived by the consumers towards the electric two-wheelers are high, then their attitude towards the electric two-wheeler will also be high. This finding from this research also matches with previous research findings of Yang et al. (2020) [47]. Consumers perceive that electric two-wheeler economic benefits attained due to reducing the fuel and maintenance cost compared to gasoline two-wheelers.

Hypothesis 3 was accepted as the $p$-value was less than 0.05 , which means that social influence (SI) positively affects $(\beta=0.198)$ consumers' attitudes (ATT) towards electric two-wheelers. The relationship was significant at a $5 \%$ level of significance. This indicates that consumers who have great social influence will have a high attitude towards electric two-wheelers. A previous study conducted by Lee et al. (2021) in Pakistan did not correlate with buying EVs. Still, the present study on E2W shows positive correlations with attitudes in India. This is supported by the previous research findings of Wang and Zhou (2019) [32]. The findings suggests that social approval of E2W significantly influences the consumers' adoption of E2W in India. Others' attitudes towards E2W are important for the potential E2W users in India, and this will affect their buying intention.

Hypothesis 4 was accepted as the $p$-value was less than 0.05 , which means that charging infrastructure (CI) positively affects $(\beta=0.199)$ consumers' attitudes (ATT) towards electric two-wheelers. The relationship was significant at a $1 \%$ level of significance and by bootstrapping $(0.012,0.38)$. This finding of this research matches the previous research findings of Wang and Zhou (2019) [32]. This indicates that if the charging infrastructure is available as per the requirement, the consumer attitude towards the electric two-wheelers will also be positive.

Hypothesis 5 was accepted as the $p$-value was less than 0.05 , which means that consumer attitude (ATT) positively affects $(\beta=0.764)$ consumer attitude (ATT) towards electric two-wheelers. The relationship was significant at a $1 \%$ level of significance and by bootstrapping $(0.691,0.825)$. The path coefficient was the highest, which shows that the consumers who show more positive attitudes towards electric two-wheelers have higher intentions to buy E2W. This indicates that if consumers' attitudes towards electric two-wheelers is high, then their intensity to purchase the two-wheeler will also be high. A few researchers have supported the conclusion that attitude positively influences adoption intention (e.g., $[47,52,78])$.

Hypothesis 6 was accepted as the $p$-value was less than 0.05 for the charging infrastructure, the perceived economic benefit, the attitude, and the intention to purchase electric two-wheelers. The $\beta$ coefficient for females was found to be higher than males in this study. This shows that female consumers show more positive attitudes and higher intention to buy electric two-wheelers in India. This finding matches the previous research findings of Habich-Sobiegalla et al. (2018) conducted in Russia and She et al. (2017) conducted in China related to purchase intentions to electric vehicles. In India, the majority of the electric two-wheelers sales come from low-speed models [79]. This supports the findings as women prefer to use electric scooters with low-speed models, but men have a preference towards high-speed models. 


\section{Conclusions and Limitations}

This research aimed to study consumers' intentions to purchase electric two-wheelers and tested the five influencing factors. Based on the literature study, we investigated the following factors: environmental concern, perceived economic benefits, social influence, charging infrastructure, and attitude.

\subsection{Theoretical Contribution}

The main contribution of this study was to empirically identify the constructs that significantly influence the consumers to purchase electric two-wheelers in India using the PLS-SEM technique. This research analysis using PLS-SEM revealed that all the four variables, EC, PEB, SI, and CI, significantly affect attitudes towards electric two-wheelers. Consumers' attitudes significantly affects their intention to purchase E2Ws. This research used a modified TPB model to study intentions to purchase electric two-wheelers. Environmental concern and charging infrastructure were added as the new variables to the existing TPB model. According to the research analysis results, consumer attitudes towards E2Ws were found to be the most important factor in influencing the intention to purchase E2Ws. The factor that influences E2W attitudes includes perceived economic benefit, social influence, environmental concern, and charging infrastructure. The findings from this research show that PEB and environmental concern are the two most important variable that influence attitudes towards E2Ws. The model fit indicators all met the ideal standards, and therefore the selected factors used in the model explain the consumers' intention to purchase E2Ws.

Another important contribution of this research was introducing gender as the moderating variable. The original TPB model did not use any moderating variables, but technology acceptance models like UTAUT and UTAUT2 suggested gender as a moderating variable to explain the model better. Based on these, gender was introduced as one of the moderating variables for this study. The results shows that female respondents of the sample showed a higher inclination to purchase electric two-wheelers in India. Including the gender as a moderating variable for this current study did explain the consumers' intention to buy electric two-wheelers in a better way.

\subsection{Practical Implications}

The research findings of this study can be used as a reference for electric two-wheeler producers when designing their marketing strategies. The air quality will improve significantly if electric two-wheelers replace gasoline two-wheelers. Since electric two-wheelers are in the early stages of adoption, potential consumers may consider various factors before buying them. The conclusion derived from the present study shows that PEB and EC are the two most important factors influencing consumers to buy electric two-wheelers in India. It is necessary to promote the advantages and importance of E2Ws for creating a clean pollution-free environment. The companies that market E2Ws can focus on explaining the economic benefits of E2Ws. The marketing proposal provided by E2W dealers could emphasize the PEB and EC as important attributes of E2Ws. Opinions of others were also found to influence the consumers' intentions to purchase E2Ws, so companies need to indicate the benefits to the public by using a variety of media.

PEB showed a positive impact on purchase intention; the government should give more financial incentives to drive the adoption of E2Ws in India. The government can take initiatives to create awareness of the environmental benefits of E2Ws, which will improve the public perceptions towards E2Ws. Charging infrastructure availability was found to be one of the important concerns of consumers. The owners of gasoline two-wheelers are unlikely to switch to an electric two-wheeler if the process of charging is difficult, time-consuming, and uncertain. The government should take steps to increase the charging infrastructure availability, which will promote the purchase of electric two-wheelers in India. Since the intention to buy E2W is influenced by the limited charging infrastructure, the building of charging infrastructure should speed up on a national scale to increase the 
adoption rate. The research also shows the women are more inclined to buy electric twowheelers as they usually travel less distance and prefer low-speed vehicles in comparison to men. Therefore, companies can target women for promoting E2Ws and can develop campaigns to match their requirements.

\subsection{Limitations and Further Studies}

One of the limitations of the research is the generalizability of the results. The research was conducted using an online survey that failed to create data from a random sample, as respondents contributed voluntarily. The second limitation of the study was that it only studied five major potential factors based on the literature review. Many other factors may affect Indian consumers' purchase intentions. Factors like E2Ws' performance, nonmonetary benefits, and consumers' knowledge can be included in future studies. The current study was conducted in India and potentially cannot be generalizable to other countries. Researchers can examine and confirm our findings in the context of other countries. The perceived benefit in this study includes only perceived economic benefits and not non-economic benefits. The non-economic benefits could be included as a separate variable for future research to find the differences in the effect between financial and nonfinancial benefits. The current studies included gender as a moderator, and future studies can include other social-demographic variables like income, age, and location. This study only studied the intention the buy and not the actual purchasing behavior. Future research can include a model to test the actual purchasing behavior.

Author Contributions: All three co-authors together contributed to the completion of this article. S.J. developed the study design, prepared the questionnaire, collected the data, and wrote the manuscript. T.G. was involved in data analysis and inference and in drafting the article. S.A. contributed to analyzing the data and supported in writing the article. All authors have read and agreed to the published version of the manuscript.

Funding: This research received no external funding.

Institutional Review Board Statement: This research was conducted according to the CMS-IRB ethical guidelines for social science research and approved by SSN School of Management Research Ethics Review Committee on 28 April 2021.

Informed Consent Statement: Informed consent was obtained from all subjects involved in the study.

Data Availability Statement: Any interested parties can contact the corresponding author directly via email for information on the data.

Acknowledgments: The authors would like to thank Sanjeev Kumar for structuring the questionnaire and data collection.

Conflicts of Interest: The authors declare no conflict of interest.

\section{Appendix A}

Table A1. Constructs Measurement Items and Its Source

\begin{tabular}{cclc}
\hline Construct & Items Code & \multicolumn{1}{c}{ Measurement Items } & Author(s) \\
\hline & EC1 & I am concerned about air pollution caused by conventional vehicles. & \\
Environmental & EC2 & It is necessary to cut down the energy consumptions. & Khurana, Kumar, and \\
concern (EC) & EC3 & I am willing to pay more to buy environmentally friendly products. & Sidhpuria (2019) [53] \\
& EC4 & It is necessary to reduce water consumption to protect natural resources. & \\
\hline \multirow{2}{*}{$\begin{array}{c}\text { Perceived } \\
\text { economic }\end{array}$} & PEB1 & Electric two-wheelers will lower my fuel expenses. & Khurana, Kumar, and \\
benefit (PEB) & PEB2 & Electric two-wheelers will reduce my vehicle maintenance costs. & Sidhpuria (2019) [53] \\
& PEB3 & The overall cost of owning an electric vehicle will be low due to government & incentives (incentives = lower road tax/less insurance premium/cheaper loan). \\
& PEB4 & Electric two-wheelers can improve my travel efficiency. & \\
\hline
\end{tabular}


Table A1. Cont.

\begin{tabular}{|c|c|c|c|}
\hline Construct & Items Code & Measurement Items & Author(s) \\
\hline \multirow{4}{*}{$\begin{array}{l}\text { Social influence } \\
\qquad(\mathrm{SI})\end{array}$} & SI1 & If I buy an electric two-wheeler, most people would agree with my decision. & \multirow{4}{*}{ Lee et al. (2021) [49] } \\
\hline & SI2 & Most people who are important to me would appreciate me if I bought an electric & \\
\hline & SI3 & If I buy an electric two-wheeler, people will find it as a sensible purchase. & \\
\hline & SI4 & Other people will not be impressed that I have purchased an eclectic two-wheeler. & \\
\hline \multirow{5}{*}{$\begin{array}{c}\text { Charging } \\
\text { infrastructure } \\
(\mathrm{CI})\end{array}$} & CI1 & $\begin{array}{l}\text { I am not satisfied with the current situation of public charge-points of electric } \\
\text { two-wheelers in the country. }\end{array}$ & \multirow{5}{*}{$\begin{array}{l}\text { Wang and Zhou } \\
\text { (2019) [32] }\end{array}$} \\
\hline & $\mathrm{CI} 2$ & $\begin{array}{l}\text { I think the charging infrastructure needs to be improved a lot to make electric } \\
\text { two-wheeler usage more convenient. }\end{array}$ & \\
\hline & $\mathrm{CI} 3$ & $\begin{array}{l}\text { I think we need charging stations and home-charging electric two-wheelers will not } \\
\text { be sufficient. }\end{array}$ & \\
\hline & CI4 & $\begin{array}{l}\text { I think battery swapping is a better technology than charging batteries of electric } \\
\text { two-wheelers in the charging points. }\end{array}$ & \\
\hline & CI5 & $\begin{array}{l}\text { I am not happy with the charging time and efficiency of the current generation of } \\
\text { batteries used for electric two-wheelers. }\end{array}$ & \\
\hline \multirow{5}{*}{ Attitude (ATT) } & ATT1 & Buying electric two-wheeler at this point of time is very wise. & \multirow{5}{*}{ Wang et al. 2018 [52] } \\
\hline & ATT 2 & Buying an electric two-wheeler at this point is very good. & \\
\hline & ATT 3 & Buying an electric two-wheeler at this point is very useful. & \\
\hline & ATT 4 & Buying an electric two-wheeler at this point is very attractive. & \\
\hline & ATT 5 & Buying an electric two-wheeler at this point is very valuable. & \\
\hline \multirow{3}{*}{$\begin{array}{l}\text { Consumer pur- } \\
\text { chase inten- } \\
\text { tion (PUIN) }\end{array}$} & PUIN1 & I intend to buy an electric two-wheeler in the near future. & \multirow{3}{*}{$\begin{array}{l}\text { Lai, Liu, Sun, Zhang, } \\
\text { and } \mathrm{Xu}, 2015 \text { [44] }\end{array}$} \\
\hline & PUIN2 & I will recommend my friend and relatives to buy an electric two-wheeler. & \\
\hline & PUIN3 & Comparing with conventional vehicles, electric vehicles are more attractive. & \\
\hline
\end{tabular}

\section{References}

1. IEA. Electric Cars had a Record Year in 2020, with Europe Overtaking China as the Biggest Market. Available online: https://www. iea.org/reports/global-ev-outlook-2021/trends-and-developments-in-electric-vehicle-markets (accessed on 26 January 2021).

2. IEA. Prospects for Electric Vehicle Deployment. Available online: https://www.iea.org/reports/global-ev-outlook-2021 / prospects-for-electric-vehicle-deployment (accessed on 7 March 2021).

3. Kumar Satyam. How Better Financing Options Can Help Drive Electric Two-Wheeler Adoption in India. Available online: https:/ / www.financialexpress.com/auto/electric-vehicles/better-financing-options-to-help-drive-electric-two-wheeleradoption-in-india-heres-how / 2308807 / (accessed on 2 October 2021).

4. Society of Indian Automobile Manufacturers (SIAM). Domestics Sales Trends. 2021. Available online: https://www.siam.in/ statistics.aspx?mpgid=8\&pgidtrail=14 (accessed on 5 October 2021).

5. Brar, L.; Burgoyne, B.; Eriksson, L.; Likhari, R.; Skoufa, T.; Williams, L. The India Electric Vehicle Opportunity: Market Entry Toolkit; Catapult Connected Places: Leeds, UK, 2021.

6. JMK Research. E-Two-Wheeler India Market Outlook. 2021. Available online: https://jmkresearch.com/electric-vehiclespublished-reports / electric-two-wheeler-india-market-outlook-2/ (accessed on 5 October 2021).

7. IQAir. World's Most Polluted Countries 2020 (PM2.5). Available online: https://www.iqair.com/us/world-most-pollutedcountries (accessed on 2 October 2021).

8. Union of Concerned Scientists. Each Country's Share of CO2 Emissions. Available online: https://www.ucsusa.org/resources/ each-countrys-share-co2-emissions (accessed on 23 June 2021).

9. NITI Aayog. NITI Aayog and World Resources Institute India Jointly Launch 'Forum for Decarbonizing Transport' in India. Available online: https:/ / pib.gov.in/PressReleasePage.aspx?PRID=1748514 (accessed on 4 March 2021).

10. Tarei, P.K.; Chand, P.; Gupta, H. Barriers to the adoption of electric vehicles: Evidence from India. J. Clean. Prod. 2021, 291, 125847. [CrossRef]

11. Wadhwa Nilesh. More Electric Two-Wheelers Sold in H1 2021 Than All of 2020. Autocar India. Available online: https: / www.autocarindia.com/bike-news/more-electric-two-wheelers-sold-in-h1-2021-than-all-of-2020-421361 (accessed on 13 October 2021).

12. Chéron, E.; Zins, M. Electric vehicle purchasing intentions: The concern over battery charge duration. Transp. Res. Part A Policy Pr. 1997, 31, 235-243. [CrossRef]

13. Coffman, M.; Bernstein, P.; Wee, S. Electric vehicles revisited: A review of factors that affect adoption. Transp. Rev. 2016, 37, 79-93. [CrossRef]

14. Eccarius, T.; Lu, C.-C. Adoption intentions for micro-mobility-Insights from electric scooter sharing in Taiwan. Transp. Res. Part D Transp. Environ. 2020, 84, 102327. [CrossRef]

15. Wang, S.; Fan, J.; Zhao, D.; Yang, S.; Fu, Y. Predicting consumers' intention to adopt hybrid electric vehicles: Using an extended version of the theory of planned behavior model. Transportation 2016, 43, 123-143. [CrossRef] 
16. Lashari, Z.; Ko, J.; Jang, J. Consumers' Intention to Purchase Electric Vehicles: Influences of User Attitude and Perception. Sustainability 2021, 13, 6778. [CrossRef]

17. Bigerna, S.; Micheli, S. Attitudes Toward Electric Vehicles: The Case of Perugia Using a Fuzzy Set Analysis. Sustainability 2018, 10, 3999. [CrossRef]

18. Will, S.; Luger-Bazinger, C.; Schmitt, M.; Zankl, C. Towards the Future of Sustainable Mobility: Results from a European Survey on (Electric) Powered-Two Wheelers. Sustainability 2021, 13, 7151. [CrossRef]

19. Rezvani, Z.; Jansson, J.; Bodin, J. Advances in consumer electric vehicle adoption research: A review and research agenda. Transp. Res. Part D: Transp. Environ. 2015, 34, 122-136. [CrossRef]

20. Habich-Sobiegalla, S.; Kostka, G.; Anzinger, N. Electric vehicle purchase intentions of Chinese, Russian and Brazilian citizens: An international comparative study. J. Clean. Prod. 2018, 205, 188-200. [CrossRef]

21. Higueras-Castillo, E.; Guillén, A.; Herrera, L.-J.; Liébana-Cabanillas, F. Adoption of electric vehicles: Which factors are really important? Int. J. Sustain. Transp. 2020, 15, 799-813. [CrossRef]

22. Ajzen, I. The Theory of Planned Behavior. Organ. Behav. Hum. Decis. Process. 1991, 50, 179-211. [CrossRef]

23. Ajzen, I.; Fishbein, M. Attitude-behavior relations: A theoretical analysis and review of empirical research. Psychol. Bull. 1977, 84, 888-918. [CrossRef]

24. Chen, M.-F. Extending the theory of planned behavior model to explain people's energy savings and carbon reduction behavioral intentions to mitigate climate change in Taiwan-moral obligation matters. J. Clean. Prod. 2016, 112, 1746-1753. [CrossRef]

25. Legris, P.; Ingham, J.; Collerette, P. Why do people use information technology? A critical review of the technology acceptance model. Inf. Manag. 2003, 40, 191-204. [CrossRef]

26. Eccarius, T.; Lu, C.-C. Powered two-wheelers for sustainable mobility: A review of consumer adoption of electric motorcycles. Int. J. Sustain. Transp. 2020, 14, 215-231. [CrossRef]

27. Venkatesh, V.; Walton, S.M.; Thong, J.Y.L. Consumer Acceptance and Use of Information Technology: Extending the Unified Theory of Acceptance and Use of Technology. MIS Quart. 2012, 36, 157-178. [CrossRef]

28. Khazaei, H.; Tareq, M.A. Moderating effects of personal innovativeness and driving experience on factors influencing adoption of BEVs in Malaysia: An integrated SEM-BSEM approach. Heliyon 2021, 7, e08072. [CrossRef]

29. Bjerkan, K.Y.; Nørbech, T.E.; Nordtømme, M.E. Incentives for promoting Battery Electric Vehicle (BEV) adoption in Norway. Transp. Res. Part D Transp. Environ. 2016, 43, 169-180. [CrossRef]

30. Lévay, P.Z.; Drossinos, Y.; Thiel, C. The effect of fiscal incentives on market penetration of electric vehicles: A pairwise comparison of total cost of ownership. Energy Policy 2017, 105, 524-533. [CrossRef]

31. Asadi, S.; Nilashi, M.; Samad, S.; Abdullah, R.; Mahmoud, M.; Alkinani, M.H.; Yadegaridehkordi, E. Factors impacting consumers' intention toward adoption of electric vehicles in Malaysia. J. Clean. Prod. 2021, 282, 124474. [CrossRef]

32. Jian, W.; Zhou, W. Factors Influencing the Purchase Willingness towards Electric Vehicles in China; Uppsala University: Uppsala, Sweden, 2019.

33. Jou, R.-C.; Chen, T.-Y. Factors affecting public transportation, car, and motorcycle usage. Transp. Res. Part A Policy Pr. 2014, 61, 186-198. [CrossRef]

34. Amron, A. Buying Decision in the Consumers of Automatic Motorcycle in Yogyakarta, Indonesia. J. Mark. Manag. 2018, 6, 275-280.

35. Guerra, E. Electric vehicles, air pollution, and the motorcycle city: A stated preference survey of consumers' willingness to adopt electric motorcycles in Solo, Indonesia. Transp. Res. Part D Transp. Environ. 2019, 68, 52-64. [CrossRef]

36. Chen, H.-S.; Tsai, B.-K.; Hsieh, C.-M. Determinants of Consumers' Purchasing Intentions for the Hydrogen-Electric Motorcycle. Sustainability 2017, 9, 1447. [CrossRef]

37. Mamun, A.-A.; Zainol, R.N.; Hayat, N. Electric Scooter-An Alternative Mode of Transportation for Malaysian Youth. Available online: https: / / www.researchsquare.com/article/rs-100232/v1 (accessed on 5 October 2021). [CrossRef]

38. Utami, M.W.D.; Yuniaristanto, Y.; Sutopo, W. Adoption Intention Model of Electric Vehicle in Indonesia. J. Optimasi Sist. Ind. 2020, 19, 70-81. [CrossRef]

39. Chirag, M.; Sonali, Y. Environmentally Conscious Consumers and Electric Vehicle Adoption Behaviour: Moderating Role of Perceived Economic Benefit. Acad. Mark. Stud. J. 2021, 25, 1-16.

40. Javid, M.A.; Ali, N.; Abdullah, M.; Campisi, T.; Shah, S.A.H. Travelers' Adoption Behavior towards Electric Vehicles in Lahore, Pakistan: An Extension of Norm Activation Model (NAM) Theory. J. Adv. Transp. 2021, 2021, 7189411. [CrossRef]

41. Tu, J.-C.; Yang, C. Key Factors Influencing Consumers' Purchase of Electric Vehicles. Sustainability 2019, 11, 3863. [CrossRef]

42. Xu, Y.; Zhang, W.; Bao, H.; Zhang, S.; Xiang, Y. A SEM-Neural Network Approach to Predict Customers' Intention to Purchase Battery Electric Vehicles in China's Zhejiang Province. Sustainability 2019, 11, 3164. [CrossRef]

43. Peters, A.; Dütschke, E. How do Consumers Perceive Electric Vehicles? A Comparison of German Consumer Groups. J. Environ. Policy Plan. 2014, 16, 359-377. [CrossRef]

44. Lai, I.K.W.; Liu, Y.; Sun, X.; Zhang, H.; Xu, W. Factors Influencing the Behavioural Intention towards Full Electric Vehicles: An Empirical Study in Macau. Sustainability 2015, 7, 12564-12585. [CrossRef]

45. Dash, A. Determinants of EVs adoption: A study on green behavior of consumers. Smart Sustain. Built Environ. 2020, 10, 125-137. [CrossRef] 
46. Orbell, S.; Crombie, I.; Johnston, G. Social cognition and social structure in the prediction of cervical screening uptake. Br. J. Health Psychol. 1996, 1, 35-50. [CrossRef]

47. Yang, C.; Tu, J.-C.; Jiang, Q. The Influential Factors of Consumers' Sustainable Consumption: A Case on Electric Vehicles in China. Sustainability 2020, 12, 3496. [CrossRef]

48. Venkatesh, V.; Davis, F.D. A Theoretical Extension of the Technology Acceptance Model: Four Longitudinal Field Studies. Manag. Sci. 2000, 46, 186-204. [CrossRef]

49. Lee, J.; Baig, F.; Talpur, M.; Shaikh, S. Public Intentions to Purchase Electric Vehicles in Pakistan. Sustainability 2021, $13,5523$. [CrossRef]

50. Avendus. Electric Vehicles: Charging Towards a Bright Future. 2020. Available online: https://www.avendus.com/crypted_pdf_ path/img_5efde54946e837.06392761_EVReport2020_Avendus.pdf (accessed on 4 June 2021).

51. Nair, S.; Rao, N.; Mishra, S.; Patil, A. India's Charging Infrastructure d Biggest Single Point Impediment in EV Adaptation in India. In Proceedings of the IEEE Transportation Electrification Conference (ITEC-India), Pune, India, 3-15 December 2017.

52. Wang, S.; Wang, J.; Li, J.; Wang, J.; Liang, L. Policy implications for promoting the adoption of electric vehicles: Do consumer's knowledge, perceived risk and financial incentive policy matter? Transp. Res. Part A Policy Pr. 2018, 117, 58-69. [CrossRef]

53. Khurana, A.; Kumar, V.V.R.; Sidhpuria, M. A Study on the Adoption of Electric Vehicles in India: The Mediating Role of Attitude. Vision J. Bus. Perspect. 2020, 24, 23-34. [CrossRef]

54. She, Z.-Y.; Sun, Q.; Ma, J.-J.; Xie, B.-C. What are the barriers to widespread adoption of battery electric vehicles? A survey of public perception in Tianjin, China. Transp. Policy 2017, 56, 29-40. [CrossRef]

55. Chen, C.-F.; de Rubens, G.Z.; Noel, L.; Kester, J.; Sovacool, B.K. Assessing the socio-demographic, technical, economic and behavioral factors of Nordic electric vehicle adoption and the influence of vehicle-to-grid preferences. Renew. Sustain. Energy Rev. 2020, 121, 109692. [CrossRef]

56. Hair, J.F.; Thomas, G.M.H.; Ringle, C.; Sarstedt, M. A Primer on Partial Least Squares Structural Equation Modeling (PLS-SEM); SAGE Publication Inc.: Thousand Oaks, CA, USA, 2012.

57. Faul, F.; Erdfelder, E.; Lang, A.-G.; Buchner, A. G*Power 3: A flexible statistical power analysis program for the social, behavioral, and biomedical sciences. Behav. Res. Methods 2007, 39, 175-191. [CrossRef] [PubMed]

58. NBSP; Cohen, J. A Power Primer. Psychol. Bull. 1992, 112, 155-159. [CrossRef]

59. Hair, J.F.; Risher, J.J.; Sarstedt, M.; Ringle, C.M. When to use and how to report the results of PLS-SEM. Eur. Bus. Rev. 2019, 31, 2-24. [CrossRef]

60. Straub, D.W. Validating Instruments in MIS Research. MIS Q. Manag. Inf. Syst. 1989, 13, 147. [CrossRef]

61. Hair, J.F., Jr.; Matthews, L.M.; Matthews, R.L.; Sarstedt, M. PLS-SEM or CB-SEM: Updated guidelines on which method to use. Int. J. Multivar. Data Anal. 2017, 1, 107. [CrossRef]

62. Anderson, J.C.; Gerbing, D.W. Structural equation modeling in practice: A review and recommended two-step approach. Psychol. Bull. 1988, 103, 411-423. [CrossRef]

63. Krabbe, P.F.M. The Measurement of Health and Health Status: Concepts, Methods and Applications from a Multidisciplinary Perspective; Academic Press: Cambridge, MA, USA, 2016.

64. Hair, J.F.; Ringle, C.M.; Sarstedt, M. Partial Least Squares Structural Equation Modeling: Rigorous Applications, Better Results and Higher Acceptance. Long Range Plan. 2013, 46, 1-12. [CrossRef]

65. Byrne, B.M. Structural Equation Modeling with AMOS; Routledge: Abingdon, UK, 2013. [CrossRef]

66. Jr., J.F.H.; Babin, B.J.; Krey, N. Covariance-Based Structural Equation Modeling in theJournal of Advertising: Review and Recommendations. J. Advert. 2017, 46, 163-177. [CrossRef]

67. Ali, F.; Rasoolimanesh, S.M.; Sarstedt, M.; Ringle, C.M.; Kisang, R. An Assessment of the Use of Partial Least Squares Structural Equation Modeling (PLS-SEM) in Hospitality Research. Int. J. Contemp. Hosp. Manag. 2018, 30, 514-538. [CrossRef]

68. Gefen, D.; Karahanna, E.; Straub, D.W. Trust and TAM in Online Shopping: An Integrated Model. MIS Q. Manag. Inf. Syst. 2003, 27. [CrossRef]

69. Sanchez, G. PLS Path Modeling with R Trowchez Editions; Trowchez Editions: Berkeley, CA, USA, 2013.

70. Fornell, C.; Larcker, D.F. Evaluating Structural Equation Models with Unobservable Variables and Measurement Error. J. Mark. Res. 1981, 18, 39-50. [CrossRef]

71. Hubley, A.M.; Zumbo, B.D. A Dialectic on Validity: Where We Have Been and Where We Are Going. J. Gen. Psychol. 1996, 123, 207-215. [CrossRef]

72. Taherdoost, H. Validity and Reliability of the Research Instrument; How to Test the Validation of a Questionnaire/Survey in a Research. SSRN Electron. J. 2018, 5, 28-36. [CrossRef]

73. Hamdollah, R.; Baghaei, P. Partial Least Squares Structural Equation Modeling with R. Pract. Assess. Res. Eval. $2016,21,21$.

74. Henseler, J.; Hubona, G.; Ray, P.A. Using PLS path modeling in new technology research: Updated guidelines. Ind. Manag. Data Syst. 2016, 116, 2-20. [CrossRef]

75. Wetzels, M.; Schröder, O.; Oppen, V. Using PLS Path Modeling for Assessing Hierarchical Construct Models: Guidelines and Empirical Illustration. MIS Q. Manag. Inf. Syst. 2009, 33, 177. [CrossRef]

76. Hair, J.F., Jr.; Sarstedt, M.; Hopkins, L.; Kuppelwieser, V.G. Partial least squares structural equation modeling (PLS-SEM): An Emerging Tool in Business Research. Eur. Bus. Rev. 2014, 26, 106-121. [CrossRef] 
77. Sarstedt, M.; Henseler, J.; Ringle, C.M. Multigroup Analysis in Partial Least Squares (PLS) Path Modeling: Alternative Methods and Empirical Results. New Chall. Int. Mark. 2011, 22, 195-218. [CrossRef]

78. Han, L.; Wang, S.; Zhao, D.; Li, J. The intention to adopt electric vehicles: Driven by functional and non-functional values. Transp. Res. Part A Policy Pract. 2017, 103, 185-197. [CrossRef]

79. Hindustan Times Auto. Electric Vehicle Sales Slump 19.4\% in FY2021 to 238,120 Units. Available online: https://auto hindustantimes.com/auto/news/electric-vehicle-sales-slump-19-4-in-fy2021-to-238-120-units-41619346113748.html (accessed on 12 October 2021). 